\title{
Statler pulchrifex
}

Make love and war.

\section{Matt Weber}

"Did I ever tell you," asked Statler, "about the time we created the most beautiful woman in the world?"

“That was us?" said Waldorf. He bowled a blue rock, which knocked Statler's red one off the board and came to rest in the three-point zone. ${ }^{\alpha}$ I thought it was MI6 for sure."

Waldorf, short and bald, had coordinated covert missions with the Army Rangers and several more obscure units; Statler, rangy and jowly, was secretive about his affiliation. They were shuffleboard buddies and imaginative hecklers of the home's cafeteria food. In the wake of a particularly inexcusable meatloaf night, Ethel R. had named them Statler and Waldorf after the Muppet hecklers; everyone had code names anyway, so the nicknames had stuck. It was the end of a warm afternoon.

"You and everyone else," said Statler. "Come on, some Oxbridge teabag's gonna engineer the most beautiful woman in the world? You need lust for that. You need to bathe in meat and oil and women. When you've spit off the edge of what human experience has to offer, then you're ready to build the most beautiful woman in the world. Anything less, you'll go running home to mama at the first teratogenesis." Statler bowled his blue rock, which sailed past the end of the board to join the one Waldorf had knocked out. 'Didn't you ever take no psychology?"

"I never learned that in class, anyway. D'you weaponize her?"

"I look like a goofball to you? Look, we spent millions on testing alone. You gotta find the subjects, you gotta get the electrodes in them, you gotta keep their paws off her, you gotta get enough data to swear up and down that the sight, the mere sight, of this piece is driving these idiots' limbic systems to the edge of the refractory period. Of course we weaponized her."

Waldorf sent a red rock into the twopoint zone. "I thought the problem with we aponizing beauty was the countermeasure. Just whip up some eunuch type and dial down the gain in the limbic units. Bang - no aesthetic response."

"Dial down the gain," snorted Statler. ${ }^{\alpha}$ Look, you could depress the synaptic strengths so your eunuch wouldn't step aside for a charging bull elephant and Miss Mata would still send their firing rates to the wall. I repeat, I look like a goofball to you?"

"You do, since you're so interested," said Waldorf. "So what next?"

${ }^{\alpha}$ The usual song and dance. Cloning, ninja training, brainwashing. You probably had some guys on it."

Statler bowled a blue rock at Waldorf's guard rock and missed. Waldorf snorted a laugh.

"Back then I could have filled out three forms to have you killed," said Statler. "For your immediate family, two. I know for a

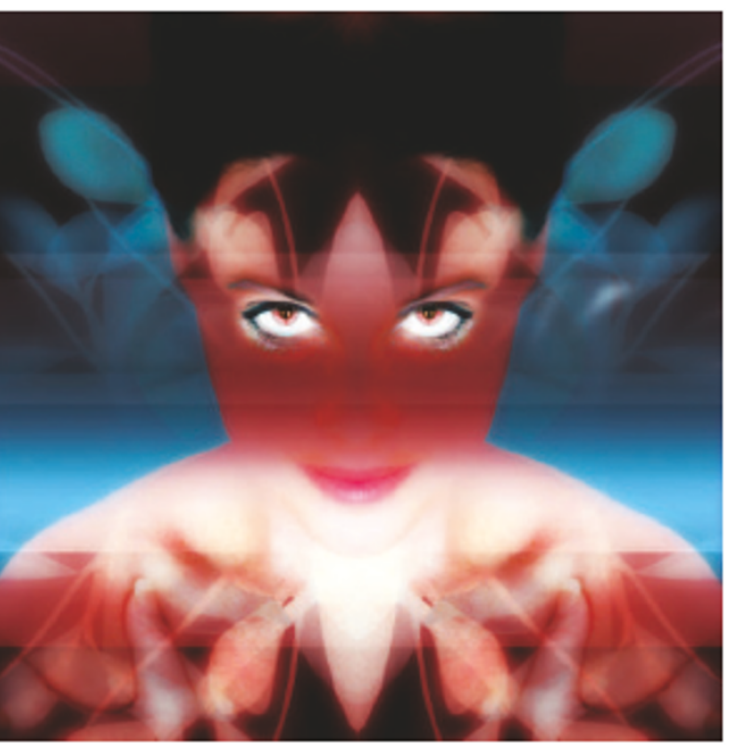

fact you'd have needed six to snuff me, and I'd have had my eye on four of them. You'd have disappeared before they cleared the comptroller."

Statler hated losing at shuffleboard.

"Well," said Waldorf, " we're not sending clones of Spooksville's Next Top Model to do all our black ops. So what went wrong?"

Statler scowled. "Nothing at first. But some genius in Delhi got wind of the project. Figured, what with the way they were snarling at Pakistan, we might send Mata to do some sabotage on their weapons systems, keep the temperature down. $\mathrm{He}$ was right, of course. And since he ${ }^{n}-$ Statler missed Waldorf's guard rock miserably - "was smarter than you, when he built the countermeasure, he did not dial down the gain. He dialled it up."

"Dialled it up." Waldorf polished the sweat from his pate. "The eunuch loved everything?"
${ }^{\alpha} \mathrm{He}$ had his balls, but yeah. To him, everything was as beautiful as Mata. $\mathrm{He}$ could barely eat for weeping and laughing. They called him the Bodhisattva Assassin."

Waldorf's rock went short, alighting just shy of the two-point line. "You're telling me some chortling Hare Krishna beat a Ranger-trained, brainwashed, sex-sweating beauty machine?"

"Sure," said Statler. ${ }^{\alpha} \mathrm{He}$ loved watching things die exactly as much as he loved anything else. That was the point of him."

Waldorf nodded.

"Imagine you go through life," Statler added, "knowing any man or woman will at least gasp and stare before trying to kill you. Every trainer, every superior you've had reinforces this impression. You get to expect breathing room. That's all it takes." Statler shook his head. "I saw the tape. Vicious stuff. He was sobbing for joy the whole time." His next bowl knocked both of Waldorf's three-point rocks from the board. "We sent a few more of her after him, just to see. Project Mata Hari, zero; transgenic Buddha, eight. So we decommissioned her, and the Bodhisattva Assassin died of a heart attack at 19, and India nuked Pakistan. The End."

"Well," said Waldorf, "it worked out all right." He squinted up at Statler. "You know a lot about Delhi's side of the story."

Statler tilted his head towards an old man standing very still on the tenth hole of the golf course. "Sanskrit was the genius behind the Bodhisattva Assassin. Told me all about it over bridge."

"How'd he get in here, then?

"Defected."

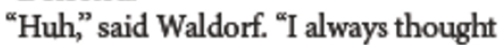
Sanskrit had something under the hood."

"Smarter than you, anyway." Statler snorted. ${ }^{\alpha}$ Dial down the gain. ${ }^{\infty}$ His final shot knocked his two-point rock to the very edge of the three-point zone. "I win."

The clear sky was darkening, the warm air gently cooling. Waldorf and Statler collected their rocks and deposited them in the wicker basket by the shuffleboard. They entered the cafeteria with the peaceful anticipation of men whose wars had already been fought.

Matt Weber is a graduate student in cognitive neuroscience at Princeton University, New Jersey. 